\title{
The Role of Organizational Culture in Promoting Sustainable Enterprise
}

\section{Constantin Ciprian IACOB ${ }^{\star}$}

\begin{tabular}{l}
\hline \multicolumn{1}{c}{ A R T I C L E I N F O } \\
\hline Article history: \\
Accepted March 2020 \\
Available online May 2020 \\
\hline JEL Classification \\
P27, P47, M11 \\
Keywords: \\
Organizational culture, Sustainable \\
enterprise, Sustainable \\
development, Performance
\end{tabular}

\section{Introduction}

Sustainable development of companies is a topic that has received increasing attention in recent years, both from management theorists and from business people. Correctly integrated in the strategies of companies the sustainability of the companies becomes a development model, which offers multiple advantages to economic units. However, changing behavior in business through a sustainable approach is proving to be an intelligent method for solving simultaneously the social, environmental, as well as the economic problems, so stringent at present.

It is undeniable that we all live in an organizational society. The essence of the reason of the organizations has been the same at all times, and the importance of belonging to a well-defined group with common concerns and interests is what makes an organization work. An organization can be defined as a group of people who, based on the division of labor, work together pursuing the same goals and objectives. Business organizations (companies, firms) have multiple objectives, one of the main objectives being the creation of profit. The business organization (company, firm) according to T. Zorlețean "is a system organized by a decision center that has a certain autonomy and which, with the help of physical and human means, produces goods and services for sale" (O. Nicolescu, (coord), E. Burdus, T. Zorletean, G. Caprarescu, I. Verboncu, I. Cochina, 1992).

\section{Literature review}

Organizational culture is one of the major problems of a company. This is researched by academics who have come to the conclusion that the cultural dimension is a central pillar in all aspects of organizational life, even in those organizations where cultural aspects receive little attention. The way people think, how they feel, what their values are, all these are guided by ideas and beliefs of their cultural nature.

Senior employees of the company are, most of the time, in one way or another, the "teachers" of the organizational culture. They emphasize what is most important, but also what is least important within the corporation, how it should be understood. Organizations practice various and multiple types of management that can develop and reproduce their values, communication and organizational culture receiving special attention. However, even in cases where top managers have special knowledge of cultural significance, there is often a lack of a deeper understanding of how people and organizations function culturally. While it is 
difficult and complex to understand the meaning of culture, the more difficult it is to apply its norms correctly. Awareness and interest in culture varies between managers and companies.

Culture is a complicated concept because it is used to cover everything, but at the same time nothing very complete. Often, culture refers to something more than a social model, for example, it most often refers to surface phenomena, rather than exploring the meanings and ideas behind them. In many cases, the term culture may be abandoned and phrases such as informal behavior patterns or social models may be used. Most times when people refer to culture they seem to do it in a very vague way and it is important to use the concept without losing focus. The concept of organizational culture is not available to the employees of a company since the beginning of the employment, but it develops along the way starting from somewhere in management and being cultivated in time through the interactions of the work group (Zorlențan, T., Burduş E., Căprărescu, Gh., 1996).

In a cultural context are often shared ideas of social and common interest and less ideas with extremely personal meanings, but there are individuals who perceive the rules and norms as an obstacle to exercising their own judgment. Individual particularities are undoubtedly important and may vary within a group, but a cultural understanding does not focus only on individual idiosyncrasies but is shared within a group or groups with the same interests.

\section{Organizational culture and management}

Undoubtedly, management has an important role in terms of organizational culture. In this sense, the role of the manager is to implement, develop, maintain or change the organizational culture within an organization, as he considers, so that the organization reaches its maximum efficiency and successfully achieves all its objectives and goals. In other words, the role of the manager vis-à-vis the organizational culture is to dominate it and to manage it, not to let himself be dominated by it.

After 1980, research was conducted which led to the conclusion that within the organizational culture there is an important component, namely the managerial culture. The managerial culture considers a system of beliefs, values, expectations and aspirations of the managers of an organization. It covers, in fact, all decisions and actions related to the achievement of the desired objectives.

The managerial culture considers the actions of the employees and how they were put into practice. Each organization integrates the decisions and actions of its employees with the planned objectives, generating a behavior that amplifies the cohesion of employees, practicing a certain leadership. This idea is called by specialists in the field: organizational anticulture. (Ovidiu Nicorexcu, Ion Verboncu, 2008)

Organizational culture and organizational behavior are in an interdependent relationship. All the forms of connection between them form a whole with which any company comes into contact.

Organizational behavior is regarded as a systematic study where knowledge is applied about how individuals and groups act within the organizations where they work, where they apply their acquired knowledge in practice. This science makes it easier for managers to observe and analyze the behavior of employees so that there is a better understanding and coordination of the groups (Cristache et al, 2019).

Regarding a sustainable enterprise, there are a number of important events with a particular value that arouse the interest, or current events, regularities and influences that took place in the external environment of the company and which influenced certain decisions at one time, the policy or the effectiveness of an action taken in the organization. This is the story that interests, the one that explains how the collectivity works beyond the individual desire and decision. Nowadays there are many companies that employ professional historians to study their company history, being a real help in analyzing their culture.

The history of an enterprise cannot be broken by its external environment. This can be economic or social and can be established through various investigations, researches, and sometimes due to the lack of accurate data it is based on the logic of evolution.

Values are very important in society, so they cannot be ignored in the organizational environment. They allow each one to evaluate what is good and what is bad, to analyze things and then to act. The values result from the experiences of the individual within the groups to which he belonged at one point, are not a reproduction of these collective values of the groups, but rather what the individual himself has thought, analyzed and finally acted. We could say, therefore, that values have two parts, one individual and one collective. Although it may seem like an element of neglect, we cannot imagine an action, decision or behavior that does not refer to a code of values that expresses the idea of good and evil of the one who leads or executes (Kardos M. et al, 2019).

There is no doubt that one of the main problems for any organizational manager is the identification of the variables, the factors that influence the organizational culture. There are both internal and external factors that put their mark on the organizational culture. Internal factors are:

The history and tradition of the organization, the way it was established, what is traditional to it. The more complex the history, the older it is, the greater is the power of influencing the organizational culture. A long history also has a high degree of continuity, conferring prestige and power of influence on the elements of culture. 
The owners of the organization are represented by a smaller or larger group of people or even a single person. Their influence on culture is considerable from the beginning. If the organization is owned by a single person or a small group of people, usually their influence is greater. When the organization is owned by a large number of shareholders, their influence is reduced, but the influence of the managers taking over the power from the owners increases (State 0., 2004).

Another factor is the management system of the organization, which by its managerial, informational, decision-making, and structural organizational characteristics influences the organizational culture. A wellmanaged management system, with an operating mechanism based on employee motivation, facilitates the formation of a strong organizational culture. Also, the managers of the organization represent a factor that substantially marks the culture of the organization. The personality of the managers and their level of training and specialty, the leadership that characterizes them, varies, reason for which the culture also varies. The employees within the organization together with the managers are one of the determining factors of the culture. Their number, professional training, age, sex, temperament influence the value system of the company (Munteanu A.I. et al., 2020).

The size of the organization that is usually expressed by its turnover, value of capital, or number of personnel is directly related to the culture of the respective organization. A large organization will have more subcultures subordinated to the main culture, while a smaller organization will have a more stable, stable culture.

The technology and technique used are factors that take into account both the degree of endowment of the enterprises and their efficiency. The last years have been marked by a pronounced technological change, increasing the degree of technical endowment of the enterprises, by flexible automation. These strongly marked the content and the ways of accomplishing the work of the employees, being reflected in the system of values, expectations and aspirations, in symbols, ceremonies, roles, statuses, myths; (Hofstede G., 1996)

The economic situation influences the size and accessibility of the resources for the employees, through the economic restrictions/facilities practiced, through the intensity of the economic stress on the evolution of the organization and the employees within it. Although the influence of the economic situation on the culture is especially noticeable when it is not good, its impact is not less important when the enterprise is economically prosperous. Another factor is the life cycle phase of the organization. This is a factor of particular importance, although it is less taken into account. In each phase of the life cycle, the organizational culture presents different parameters, which must be defined and taken into account.

Undoubtedly, management has an important role in terms of organizational culture. In this sense, the manager's role is to implement, develop, maintain or change the organizational culture within an organization, as he sees it, so that the organization reaches its maximum efficiency and successfully achieves all the objectives and goals proposed. In other words, the manager's role vis-à-vis the organizational culture is to dominate it and to manage it, not to be dominated by it (Nastase M. et al, 2020).

It is desired that the employees adapt as easily as possible to the economic and competitive environment, to be efficient and motivated. In the opinion of Gilles Lipovetsky (1996, p. 309) "technical transformations or internal promotions are no longer sufficient, mentalities must be changed, the relationship of the individual with himself and with the group must be changed, employees must be trained to show creativity, to be able to adapt and communicate. The enterprise glorifies the individual autonomy, but at the same time, it makes it a norm that must be fulfilled".

Geert Hofstede delineates in his book four dimension pairs of managerial culture (Hofstede G., 1996): the first is the distance towards power, determined according to the distribution of resources and power in society; in fact, it means the distribution of power, authority and motivations within a social system and in the degree of centralization of managerial systems.

\section{Conclusions}

Organizational culture and behavior are the essence of an organization/ company/institution, which reflect both internal and external equilibrium through: the related profit, the business environment, sustainable development and last but not least public opinion about the respective institution.

The attitudes and preferences of the management influence the way the work is carried out, the atmosphere in the internal environment and what is transmitted in the external environment. The sustainable private enterprise has its own management, and the sustainable public enterprise has a management influenced by the local and county organizations. The managerial culture is also exercised in the organizational culture, in the economy, in the profits, in the organizational system. One of the differences lies in how the efficiency of the organizational system is appreciated. It can be concluded that the organization system of the private enterprise satisfies its employees to greater degree, as opposed to the employees of the public hospital who are not as satisfied. The management of an enterprise has a duty to deal with it in such a way that it works as good as possible, as it will always be compared to the competition. The organizational climate is very important because it can influence the way the internal staff provide their services. 
The common priority objectives of the two public or private companies regarding the internal organization are: strengthening the relations between the employees, cultivating the values, traditions, motivating and increasing the confidence of the employees, developing a participative management, cultivating the confidence of the employees, carrying out programs and trainings that help those in management positions (middle manager or top manager) and auxiliary employees to benefit from continuous learning and professional development.

Also at the management level, decisions can be made to favor the development of the internal environment, communication and organizational behavior. Both in a public and a private enterprise, the personnel in a management position and the auxiliary staff must be constantly informed of the established goals, both in the long term and in the short term. In order to improve the communication, both the hierarchical and the intercollegiate one, cohesion must first be developed on compartments and then on the level of the sustainable enterprise.

\section{Acknowledgement:}

This work is supported by project POCU 125040, entitled"Development of the tertiary university education to support the economic growth -PROGRESSIO", co-financed by the European Social Fund under the Human CapitalOperational Program 2014-2020.

\section{References}

1. Barclay J., (2001), Improving selection interviews with structure: organizations' use of 'behavioral' interviews, Personnel Review.

2. Beck B. E. F., Moore L. F., (1985), Linking the host culture to organizational variables, Beverly Hills; $D$.

3. Cristache, N., Năstase, M., Petrariu, R. and Florescu, M., 2019. Analiza efectelor forțelor de congruență asociate implementă rii unui cod de responsabilitate socială asupra sustenabilității firmelor din domeniul bioeconomiei. Amfiteatru Economic, 21(52), pp. 536-553

4. Handy Ch. (1986), L'Olympe des managers: culture d'enterprise et organization. Paris: d'Organisation.

5. Silvia Elena IACOB (2014) "Controversies concerning the concept of sustainable development", publicat în Valahian Journal of Economic Studies, Nr 2, Volumul 5/2014, BDI: EBSCO, DOAJ, Cabell's Diresctories, Proquest, RePec, ISSN-L 2067-9440 / ISSN 2344-4924, pp 91-98, http://www.vjes.eu/index.php/archive.html

6. Kardos Mihaela, Gabor Rozalia, Nicoleta Cristache, Green Marketing's Roles in Sustainability and Ecopreneurship. Case Study: Green Packaging's Impact on Romanian Young Consumers' Environmental Responsibility, Sustainability, no 3/11/2019

7. IACOB Silvia-Elena, Popescu Constantin (2015), „Towards a sustainable economy”, Economie teoretică şi aplicată, Vol. 604, Nr. 3, 2015, pg. 219 - 230, ISSN:1841-8678, http://store.ectap.ro/articole/1121.pdf

8. Meyerson J. M., (1987), Cultural change: an integration of three different views, Journal of Management Studies.

9. Munteanu A.I., Bibu N. , Nastase M. , Cristache N., Matis C., Analysis of Practices to Increase the Workforce Agility and to Develop a Sustainable and Competitive Business, Sustainability, 12/9/2020.

10. Năstase M., Burlacu S., Matis C., Cristache N, Roja A., Coroban L, Cristescu I, Perspectives regarding the organizational culture within the Romanian textile industry, Revista Industria Textilă, no. 1/70/2020, p.73

11. Petelean A., (2003), Managementul resurselor umane, curs IFRD, ediţia a II-a, Universitatea „Petru Maior”, Tg.-Mureș.

12. State O., (2004), Cultura organizaţiei şi managementul, Editura ASE, Bucureşti.

13. Stoica, M. (2003), Psihologie organizationala. Editura Dimitrie Cantemir, Targu-Mures.

14. Trompenaars F., (1993), Riding the waves of culture: understanding cultural diversity in business, London: Brealey, 1993.

15. Zlate M. (2004), Tratat de psihologie organizational-manageriala vol. I, Editura Polirom, Iasi.

16. Zlate, M. (2001), Coaching-ul - un tip eficient de interventie organizationala, in Revista de Psihologie Organizationala vol. I, nr.2. 